\title{
Second-hand smoke exposure in Canada: Prevalence, risk factors, and association with respiratory and cardiovascular diseases
}

\author{
Nicholas Vozoris MHSc MD ${ }^{1}$, M Diane Lougheed MD MSc ${ }^{1,2}$
}

\begin{abstract}
N Vozoris, MD Lougheed. Second-hand smoke exposure in Canada: Prevalence, risk factors, and association with respiratory and cardiovascular diseases. Can Respir J 2008;15(5):263-269.
\end{abstract}

OBJECTIVES: The aims of the present study were to estimate the prevalence of second-hand smoke exposure in Canada, to identify sociodemographic risk factors for second-hand smoke exposure, and to examine the relationship between second-hand smoke exposure and respiratory and cardiovascular diseases.

METHODS: Data from the 2000/2001 Statistics Canada Canadian Community Health Survey ( $\mathrm{n}=130,880$, aged 12 years or older) were analyzed. Second-hand smoke exposure was based on self-report within the past month. The presence of chronic health conditions was also based on self-report. Because ex-smokers would be expected a priori to have poorer health than never-smokers, the analysis was stratified by previous smoking status.

RESULTS: Approximately 25\% of never-smokers and 30\% of ex-smokers self-reported recent second-hand smoke exposure. The following factors were identified as risk factors for second-hand smoke exposure: men; residences in Quebec, Atlantic Canada and the Territories; younger ages; nonimmigrant status; low education and income levels; social assistance receipt; and households without children younger than 12 years of age. After controlling for potential confounders, both never- and ex-smokers exposed to second-hand smoke had significantly higher odds of self-reporting asthma (20\% to $30 \%$ ) and chronic bronchitis (50\%) than those not exposed to secondhand smoke. Among ex-smokers, those exposed to second-hand smoke also had significantly higher odds of self-reporting hypertension $(20 \%)$ than those not exposed to second-hand smoke. No associations were observed between second-hand smoke exposure and emphysema or heart disease.

CONCLUSIONS: Self-reported recent second-hand smoke exposure in Canada in 2000/2001 was high, and was associated with asthma, chronic bronchitis and hypertension in never- and ex-smokers. Potential causal associations and public health implications warrant additional research.

Key Words: Asthma; COPD; Epidemiology; Heart disease; Passive smoking

W hile the health hazards of mainstream smoking are well recognized, the relationship between second-hand smoke exposure and disease is a highly contentious issue. Many epidemiological studies have found second-hand smoke exposure

\section{Exposition à la fumée secondaire au Canada : Prévalence, facteurs de risque et lien avec les maladies respiratoires et cardiovasculaires}

OBJECTIFS : Les buts de la présente étude étaient d'estimer la prévalence de l'exposition à la fumée secondaire au Canada, d'identifier les facteurs de risque sociodémographiques d'exposition à la fumée secondaire et d'examiner le lien entre l'exposition à la fumée secondaire et les maladies respiratoires et cardiovasculaires.

MÉTHODES : Les auteurs ont analysé les données de l'Enquête sur la santé dans les collectivités canadiennes de Statistique Canada pour 2000. 2001 ( $\mathrm{n}=130$ 880, âgés de 12 ans ou plus). L'exposition à la fumée secondaire a été évaluée par déclaration des intéressés au cours du mois écoulé, de même que la présence de maladies chroniques. Étant donné que les ex-fumeurs seraient a priori susceptibles d'être en moins bonne santé que les gens qui n'ont jamais fumé, l'analyse a été stratifiée en fonction des antécédents tabagiques.

RÉSULTATS : Environ $25 \%$ des gens qui n'avaient jamais fumé et $30 \%$ des ex-fumeurs ont signalé avoir été exposés à de la fumée secondaire. Les facteurs suivants ont été identifiés parmi les facteurs de risque d'exposition à la fumée secondaire : sexe masculin, lieu de résidence (Québec, provinces de l'Atlantique et territoires), jeune âge, statut non immigrant, faible degré d'instruction, statut d'assisté social et foyers sans enfants de moins de 12 ans. Après vérification des facteurs de confusion potentiels, les personnes n'ayant jamais fumé et les ex-fumeurs exposés à de la fumée secondaire présentaient un risque significativement plus élevé de déclarer souffrir d'asthme (de $20 \%$ à $30 \%$ ) et de bronchite chronique (50\%) que ceux qui n'avaient jamais été exposés à de la fumée secondaire. Parmi les ex-fumeurs, ceux qui étaient été exposés à de la fumée secondaire étaient également significativement plus susceptibles de signaler souffrir d'hypertension $(20 \%)$ que les sujets n'ayant jamais été exposés à de la fumée secondaire. Aucun lien n'a été observé entre l'exposition à la fumée secondaire et l'emphysème ou la maladie cardiaque.

CONCLUSION : Les cas autodéclarés d'exposition récente à la fumée secondaire au Canada en 2000-2001 ont été nombreux et ils sont associés à l'asthme, à la bronchite chronique et à l'hypertension chez des gens n'ayant jamais fumé et chez les ex-fumeurs. Les liens de cause à effet potentiels et les conséquences pour la santé publique justifient que la recherche se poursuive dans ce domaine.

\footnotetext{
${ }^{1}$ Department of Medicine, Queen's University; ${ }^{2}$ Clinical Research Centre, Kingston General Hospital, Kingston, Ontario

Correspondence and reprints: Dr Nicholas Vozoris, Division of Respirology, Department of Medicine, University of Toronto, Medical Sciences Building, Room 6263, 1 King's College Circle, Toronto, Ontario M5S 1A8. Telephone 416-978-1562, fax 416-971-2112,

e-mail nick.vozoris@utoronto.ca
} 
are over-stated or nonexistent (26-35). Several expert panels have concluded that second-hand smoke exposure is a cause of cardiovascular disease (36-42), but they could not draw firm conclusions on a causal association between second-hand smoke exposure and adult asthma or COPD. The discrepancy in results among studies may be related to the use of different methods to assess second-hand smoke exposure and whether potential confounders were controlled for (eg, sociodemographic factors, occupational exposures) $(1-35,43)$.

There are limited data on the prevalence of second-hand smoke exposure among adults in Canada (44) and internationally (18,45-50), and which sociodemographic groups are at greatest risk for exposure (7,45,46,51-53). Using data from the 2003 Canadian Community Health Survey (CCHS), Pérez (44) reported a national prevalence of second-hand smoke exposure in Canada of 33\%. This prevalence estimate and the reported associations with limited sociodemographic variables are potentially problematic, because the 2003 CCHS did not take into consideration second-hand smoke exposure in private places such as friends' or relatives' homes, and did not reliably ascertain personal exposure in homes or workplaces. To date, associations with chronic respiratory disease and cardiovascular disease in Canada have been minimally explored (54).

The objectives of the present study were to estimate the prevalence of second-hand smoke exposure in Canada while controlling for previous smoking status, to identify sociodemographic characteristics of individuals most likely to lead to exposure, and to examine the relationship between secondhand smoke exposure and disease (particularly respiratory diseases) in never- and ex-smokers, via an analysis of data from the 2000/2001 CCHS.

\section{METHODS}

\section{Data}

The present study was conducted using data from the public use microdata file for the 2000/2001 CCHS Cycle 1.1. The CCHS is an ongoing survey conducted by Statistics Canada that collects cross-sectional, self-reported, sociodemographic and health data on Canadians aged 12 years and older. A detailed description of the survey design and methodology has been previously published $(44,55-57)$. The response rate was $84.7 \%$ (44), yielding a total sample of 130,880 respondents.

\section{Second-hand smoke exposure}

Cycle 1.1 of the CCHS was selected for analysis because of the strength of its assessment question for second-hand smoke exposure. Unlike the subsequent cycle, the 2000/2001 CCHS Cycle 1.1 included the following question on second-hand smoke exposure that was asked only of current nonsmokers: "In the past month, were you exposed to second-hand smoke on most days?" The strengths of this question are that it directly asks about regular, recent second-hand smoke exposure, it is not limited by location of exposure, and it attempts to capture significant exposure history by asking whether it occurs "on most days". One limitation of this survey question is that it limits exposure to only the preceding month. Those who responded affirmatively to the question were classified as being exposed to second-hand smoke, while those who responded negatively were classified as not being exposed to second-hand smoke.

Because ex-smokers would a priori be expected to have poorer health than never-smokers, all of the analyses were stratified by previous smoking status, as defined by the response to the following survey question: "Have you ever smoked a whole cigarette?" Those who responded affirmatively to this question were classified as ex-smokers, while those who responded negatively were classified as never-smokers. Although a conventional definition of never-smoking is smoking 100 cigarettes or fewer in one's life, a strict definition of never-smoking (ie, never having smoked a whole cigarette) was specifically selected. The consumption of 100 cigarettes or fewer to denote a never-smoker is an arbitrary cut-off number, and there is no evidence to date to suggest what threshold of cigarette smoking is required to cause disease (42).

The survey also asked questions about places of secondhand smoke exposure among those exposed: "In the past month, were you exposed to second-hand smoke at home; in a car or other vehicle; in public places; while visiting friends or relatives?" Second-hand smoke exposure at work was explored by the following survey question: "At your place of work, what are the restrictions on smoking?" Possible responses included the following: "restricted completely", "allowed in designated areas", "restricted only in certain places", "not restricted at all”, "don't know", refused or not stated. Those who responded that smoking at work was completely restricted were classified as not having been exposed to second-hand smoke at their workplace, while all other respondents were classified as having been exposed to second-hand smoke at their workplace.

\section{Sociodemographic and health variables}

All sociodemographic and health variables were based on selfreport. The following sociodemographic variables were examined: sex, province, age, race, immigration status, education level, income source, income level and whether children younger than 12 years of age resided in the household. Sex, province and age were chosen because they have been previously shown to be associated with second-hand smoke exposure (44). Education level, income source, income level, race and immigration status were chosen to examine whether exposure to second-hand smoke was associated with indexes of socioeconomic status. The presence of children younger than 12 years of age in the household was selected to determine whether it was a protective factor with respect to second-hand smoke exposure risk.

The following chronic health conditions were examined: asthma, chronic bronchitis, emphysema, heart disease and hypertension. These health conditions were chosen because previous epidemiological research have found them to be associated with second-hand smoke exposure (1-25). Respondents were classified as having a particular condition only if they reported that it lasted or was expected to last for six months or longer, and that it had been diagnosed by a health care professional.

\section{Statistical methods}

All analyses were performed using SAS version 9.1 (SAS Institute, USA). Cross-tabulations were calculated to estimate the prevalence of second-hand smoke exposure. Crosstabulations and multiple logistic regression were used to examine the association between second-hand smoke exposure and the selected sociodemographic and health variables. Unadjusted odds of an individual exposed to second-hand smoke reporting the selected health conditions were calculated. Sex, province, age group, immigration status, education level, 


\begin{tabular}{|c|c|c|}
\hline Smoking status & n (\%) & Population number \\
\hline \multicolumn{3}{|l|}{ Nonsmokers } \\
\hline Exposed to SHS & $26,795(27.7)$ & $5,279,405$ \\
\hline Not exposed to SHS & $69,922(72.3)$ & $13,776,824$ \\
\hline Total & $96,717(100)$ & $19,056,229$ \\
\hline \multicolumn{3}{|l|}{ Never-smokers } \\
\hline Exposed to SHS & $12,284(25.3)$ & \\
\hline Not exposed to SHS & $36,256(74.7)$ & \\
\hline Total & $48,540(100)$ & \\
\hline \multicolumn{3}{|l|}{ Ex-smokers } \\
\hline Exposed to SHS & $14,511(30.1)$ & \\
\hline Not exposed to SHS & $33,666(69.9)$ & \\
\hline Total & $48,177(100)$ & \\
\hline
\end{tabular}

income source and level, and the presence of children younger than 12 years of age in the household were then included in a single regression model to control for their potentially confounding effects on the odds of reporting the selected health conditions, because all of these variables were found to be independent risk factors for second-hand smoke exposure.

The CCHS uses a complex sampling design, involving stratification and multistage clustering techniques. To account for the effects of stratification, all results were weighted using the sample weights provided in the public use microdata file. All sample weights were rescaled before each analysis by dividing the original weight by the average weight of respondents included in the specific analysis, according to Statistics Canada guidelines (55). To account for the effects of clustering, all CIs were calculated using bootstrap resampling techniques, with a set of 500 bootstrap weights created by Statistics Canada to reflect the sampling design used in the survey.

\section{RESULTS}

Of the 130,880 survey respondents, 96,717 (73.9\%) were current nonsmokers. This sample of current nonsmokers included 48,540 never-smokers and 48,177 ex-smokers. Approximately $25 \%$ of never-smokers and $30 \%$ of ex-smokers self-reported recent second-hand smoke exposure, representing a total of 5.3 million Canadians (Table 1).

The most frequently self-reported sites of second-hand smoke exposure were public places and the workplace $(60 \%$ to $75 \%$ ), but exposure was commonly reported in private locations such as homes of respondents, homes of relatives or friends, and vehicles (Table 2). Sex, province, age, immigration status, education level, income source, income level and whether young children resided in the household were all independent risk factors for self-reported second-hand smoke exposure regardless of previous smoking status (Tables 3 and 4).

Among never-smokers, those exposed to second-hand smoke were more likely to report asthma and less likely to report heart disease and hypertension. There were no associations observed with chronic bronchitis and emphysema. After adjusting for potential confounders, however, second-hand smoke exposure was positively associated with chronic bronchitis, but there was
TABLE 2

Frequency of self-reported sites of second-hand smoke (SHS) exposure among nonsmokers who report exposure, stratified by previous smoking status

\begin{tabular}{lcc}
$\begin{array}{l}\text { Place of } \\
\text { SHS exposure }\end{array}$ & $\begin{array}{c}\text { Never-smokers, } \mathbf{~ ( \% ) ~} \\
(\mathbf{n = 1 2 , 2 8 4 )}\end{array}$ & $\begin{array}{c}\text { Ex-smokers, } \mathbf{~ ( \% ) ~} \\
(\mathbf{n = 1 4 , 5 1 1 )}\end{array}$ \\
\hline Public place & $8755(70.8)$ & $10,978(75.2)$ \\
Workplace & $7752(62.7)$ & $8912(61.0)$ \\
Homes of friends or relatives & $6939(56.1)$ & $9120(62.5)$ \\
Home of respondent & $5560(45.0)$ & $5930(40.6)$ \\
Car or other vehicle & $4399(35.6)$ & $5226(35.8)$ \\
\hline
\end{tabular}

now no association with heart disease and hypertension. The remainder of the disease associations remained unchanged (Table 5). Among ex-smokers, those exposed to second-hand smoke were more likely to report asthma and chronic bronchitis, less likely to report heart disease and hypertension, and there were no associations with emphysema. After adjusting for potential confounders, however, second-hand smoke exposure was positively associated with hypertension and there was now no association with heart disease. The remainder of the disease associations remained unchanged (Table 6).

\section{DISCUSSION}

The prevalence of self-reported recent second-hand smoke exposure on most days among current nonsmokers in Canada in 2000/2001 was high (27.7\%). The most frequently selfreported sites of second-hand smoke exposure were public places and the workplace, but exposure was commonly reported in private locations as well. The following factors were identified as risk factors for second-hand smoke exposure: men; residences in Quebec, Atlantic Canada and the Territories; younger ages; nonimmigrant status; low education and income levels; social assistance receipt; and households without children younger than 12 years of age. After controlling for potential confounders, both never- and ex-smokers exposed to second-hand smoke had significantly higher odds of selfreporting asthma (20\% to $30 \%)$ and chronic bronchitis (50\%) than those not exposed. Among ex-smokers, those exposed to second-hand smoke also had significantly greater odds of selfreporting hypertension (20\%). No associations were observed between second-hand smoke exposure and emphysema or heart disease.

The present study has several limitations that must be acknowledged. The cross-sectional nature of the data does not support causal inferences. Findings were based entirely on selfreported measures, thereby potentially introducing recall and social desirability biases. The fact that the survey question limited exposure to within the preceding month and that we are trying to relate exposure to chronic disease outcomes is a limitation of the analysis. Our method of stratification by previous smoking status may result in some misclassification, potentially underestimating the risk of disease among never-smokers if a significant proportion of individuals with trivial smoking history were classified as ex-smokers. The risk of disease among those exposed to second-hand smoke may also be underestimated because second-hand smoke exposure was limited to 'most days during the past month'. Subjects exposed to second-hand smoke in one-half or fewer days per month would have been classified as 'not exposed', although exposure to second-hand smoke could 
TABLE 3

Sociodemographic profile of never-smokers $(n=48,540)$ by second-hand smoke (SHS) exposure status

\begin{tabular}{|c|c|c|c|c|}
\hline Factor & $\mathbf{n}$ & $\begin{array}{c}\text { Exposed } \\
\text { to SHS, \% } \\
\text { ( } n=12,284 \text { ) }\end{array}$ & $\begin{array}{c}\text { Not } \\
\text { exposed } \\
\text { to SHS, \% } \\
(n=36,256)\end{array}$ & $\begin{array}{l}\text { Adjusted OR } \\
(95 \% \mathrm{Cl})^{*} \text { for } \\
\text { reporting SHS } \\
\text { exposure }\end{array}$ \\
\hline \multicolumn{5}{|l|}{ Sex } \\
\hline Male & 20,560 & 28.0 & 72.0 & 1.0 \\
\hline Female & 27,980 & 23.3 & 76.7 & $0.9(0.8-0.9)$ \\
\hline \multicolumn{5}{|l|}{ Area of residence } \\
\hline Atlantic Canada & 3343 & 30.3 & 69.7 & $1.3(1.1-1.4)$ \\
\hline Quebec & 10,323 & 32.2 & 67.8 & $1.5(1.4-1.7)$ \\
\hline Ontario & 20,118 & 22.8 & 77.2 & 1.0 \\
\hline Western Canada & 14,667 & 22.7 & 77.3 & $0.9(0.8-1.0)$ \\
\hline Territories & 90 & 28.8 & 71.2 & $1.2(1.0-1.4)$ \\
\hline \multicolumn{5}{|l|}{ Age group, years } \\
\hline $12-19$ & 10,848 & 35.2 & 64.8 & $1.4(1.3-1.6)$ \\
\hline $20-29$ & 8105 & 31.9 & 68.1 & $1.4(1.3-1.5)$ \\
\hline $30-49$ & 15,885 & 22.3 & 77.7 & 1.0 \\
\hline$\geq 50$ & 13,702 & 17.0 & 83.0 & $0.7(0.7-0.8)$ \\
\hline \multicolumn{5}{|l|}{ Race } \\
\hline Caucasian & 36,898 & 26.3 & 73.7 & 1.0 \\
\hline Visible minority & 10,951 & 22.2 & 77.8 & $1.0(0.9-1.1)$ \\
\hline Not stated & 691 & - & - & - \\
\hline \multicolumn{5}{|l|}{ Immigrant } \\
\hline Yes & 13,859 & 18.9 & 81.1 & $0.7(0.6-0.8)$ \\
\hline No & 34,276 & 28.0 & 72.0 & 1.0 \\
\hline Not stated & 405 & - & - & - \\
\hline \multicolumn{5}{|l|}{ Education level $^{\dagger}$} \\
\hline Less than secondary & 16,570 & 29.0 & 71.0 & $1.1(0.9-1.2)$ \\
\hline Secondary & 7813 & 27.7 & 72.3 & $1.1(1.0-1.3)$ \\
\hline Some postsecondary & 3674 & 29.0 & 71.0 & 1.0 \\
\hline Postsecondary & 20,133 & 20.8 & 79.2 & $0.8(0.7-0.9)$ \\
\hline Not stated & 350 & - & - & - \\
\hline \multicolumn{5}{|l|}{ Income source ${ }^{\ddagger}$} \\
\hline Employment & 37,231 & 27.2 & 72.3 & 1.0 \\
\hline $\begin{array}{l}\text { Unemployment } \\
\text { insurance, } \\
\text { worker's compensa } \\
\text { or welfare }\end{array}$ & sation & 36.5 & 63.5 & $1.3(1.1-1.6)$ \\
\hline Senior's benefits & 6576 & 14.7 & 85.6 & $0.5(0.5-0.6)$ \\
\hline Other & 1556 & 19.8 & 80.2 & $0.7(0.6-0.8)$ \\
\hline Not stated & 1889 & - & - & - \\
\hline \multicolumn{5}{|l|}{ Income adequacy§ } \\
\hline Lowest income & 1575 & 27.3 & 72.7 & $1.1(0.9-1.3)$ \\
\hline Lower-middle & 3439 & 26.0 & 74.0 & $1.1(1.0-1.3)$ \\
\hline Middle & 9865 & 27.1 & 72.9 & $1.1(1.0-1.3)$ \\
\hline Upper-middle & 14,448 & 26.9 & 73.1 & 1.0 \\
\hline Highest & 13,253 & 22.2 & 77.8 & $0.8(0.7-0.8)$ \\
\hline Not stated & 5960 & - & - & - \\
\hline \multicolumn{5}{|c|}{ Children younger than 12 years of age in household } \\
\hline Yes & 33,970 & 25.9 & 74.1 & $0.8(0.7-0.8)$ \\
\hline No & 14,571 & 23.9 & 76.1 & 1.0 \\
\hline
\end{tabular}

*Adjusted for other variables listed in table; ${ }^{\dagger}$ Refers to the highest level of education that the respondents attained; $¥$ Refers to the main source of household income; §Income level was defined as a five-level categorical variable describing income adequacy, and was based on information about gross total household income in the past 12 months and family size
TABLE 4

Sociodemographic profile of ex-smokers $(n=48,177)$ by second-hand smoke (SHS) exposure status

\begin{tabular}{|c|c|c|c|c|}
\hline Factor & $\mathbf{n}$ & $\begin{array}{l}\text { Exposed } \\
\text { to SHS, \% } \\
(n=14,511)\end{array}$ & $\begin{array}{c}\text { Not } \\
\text { exposed } \\
\text { to SHS, \% } \\
(n=33,666)\end{array}$ & $\begin{array}{l}\text { Adjusted OR } \\
(95 \% \mathrm{CI})^{*} \text { for } \\
\text { reporting SHS } \\
\text { exposure }\end{array}$ \\
\hline \multicolumn{5}{|l|}{ Sex } \\
\hline Male & 25,635 & 32.2 & 67.8 & 1.0 \\
\hline Female & 22,542 & 27.8 & 72.2 & $0.7(0.7-0.8)$ \\
\hline \multicolumn{5}{|l|}{ Area of residence } \\
\hline Atlantic Canada & 3971 & 32.7 & 67.3 & $1.1(1.0-1.2)$ \\
\hline Quebec & 11,891 & 36.3 & 63.8 & $1.4(1.3-1.5)$ \\
\hline Ontario & 17,652 & 27.5 & 72.5 & 1.0 \\
\hline Western Canada & 14,539 & 27.5 & 72.5 & $0.9(0.9-1.0)$ \\
\hline Territories & 125 & 37.1 & 62.9 & $1.3(1.1-1.5)$ \\
\hline \multicolumn{5}{|l|}{ Age group, years } \\
\hline 12-19 & 2474 & 57.9 & 42.1 & $2.1(1.9-2.4)$ \\
\hline $20-29$ & 5684 & 43.3 & 56.7 & $1.6(1.4-1.7)$ \\
\hline $30-49$ & 18,488 & 30.8 & 69.2 & 1.0 \\
\hline$\geq 50$ & 21,531 & 22.8 & 77.2 & $0.7(0.6-0.8)$ \\
\hline \multicolumn{5}{|l|}{ Race } \\
\hline Caucasian & 43,959 & 30.0 & 70.0 & 1.0 \\
\hline Visible minority & 3691 & 30.3 & 69.7 & $1.0(0.9-1.2)$ \\
\hline Not stated & 527 & - & - & - \\
\hline \multicolumn{5}{|l|}{ Immigrant } \\
\hline Yes & 8481 & 22.9 & 77.1 & $0.7(0.7-0.8)$ \\
\hline No & 39,392 & 31.7 & 68.3 & 1.0 \\
\hline Not stated & 304 & - & - & - \\
\hline \multicolumn{5}{|l|}{ Education level ${ }^{\dagger}$} \\
\hline Less than secondary & 11,516 & 36.0 & 64.0 & $1.3(1.1-1.4)$ \\
\hline Secondary & 8876 & 33.5 & 66.5 & $1.1(1.0-1.3)$ \\
\hline Some postsecondary & 3764 & 33.0 & 67.0 & 1.0 \\
\hline Postsecondary & 23,639 & 25.4 & 74.6 & $0.8(0.7-0.9)$ \\
\hline Not stated & 382 & - & - & - \\
\hline \multicolumn{5}{|l|}{ Income source $\ddagger$} \\
\hline Employment & 34,191 & 33.5 & 66.5 & 1.0 \\
\hline $\begin{array}{l}\text { Unemployment } \\
\text { insurance, } \\
\text { worker's compensa } \\
\text { or welfare }\end{array}$ & 1203 & 46.4 & 53.6 & $1.1(1.0-1.4)$ \\
\hline Senior's benefits & 9942 & 18.4 & 81.6 & $0.5(0.4-0.5)$ \\
\hline Other & 1591 & 20.3 & 79.7 & $0.5(0.4-0.6)$ \\
\hline Not stated & 1250 & - & - & - \\
\hline \multicolumn{5}{|l|}{ Income adequacy§ } \\
\hline Lowest income & 1167 & 37.5 & 62.5 & $1.3(1.1-1.6)$ \\
\hline Lower-middle & 2557 & 35.3 & 64.7 & $1.4(1.2-1.6)$ \\
\hline Middle & 8828 & 32.3 & 67.7 & $1.2(1.1-1.3)$ \\
\hline Upper-middle & 15,911 & 31.5 & 68.5 & 1.0 \\
\hline Highest & 14,986 & 25.9 & 74.1 & $0.8(0.7-0.8)$ \\
\hline Not stated & 4728 & - & - & - \\
\hline \multicolumn{5}{|c|}{ Children younger than 12 years of age in household } \\
\hline Yes & 36,692 & 29.9 & 70.1 & $0.8(0.7-0.9)$ \\
\hline No & 11,485 & 30.8 & 69.2 & 1.0 \\
\hline
\end{tabular}

${ }^{*}$ Adjusted for other variables listed in table; ${ }^{\dagger}$ Refers to the highest level of education that the respondents attained; $¥$ Refers to the main source of household income; §Income level was defined as a five-level categorical variable describing income adequacy, and was based on information about gross total household income in the past 12 months and family size 
TABLE 5

Odds of reporting selected chronic conditions among never-smokers $(n=48,540)$ by second-hand smoke (SHS) exposure status

\begin{tabular}{lccc}
\hline Chronic condition & $\mathbf{n ~ ( \% ) ^ { * }}$ & $\begin{array}{c}\text { Unadjusted } \\
\text { OR (95\% Cl) }\end{array}$ & $\begin{array}{c}\text { Adjusted } \\
\text { OR }^{\dagger} \mathbf{( 9 5 \% ~ C l )}\end{array}$ \\
\hline Asthma & 3984 & & \\
$\quad$ Exposed to SHS & $(10.7)$ & $1.5(1.3-1.7)$ & $1.3(1.1-1.5)$ \\
$\quad$ Not exposed to SHS & $(7.4)$ & 1.0 & 1.0 \\
Chronic bronchitis & 758 & & \\
Exposed to SHS & $(1.9)$ & $1.3(1.0-1.6)$ & $1.5(1.2-1.8)$ \\
Not exposed to SHS & $(1.5)$ & 1.0 & 1.0 \\
Emphysema & 131 & & $1.7(0.8-3.5)$ \\
Exposed to SHS & $(0.6)$ & $1.4(0.8-2.7)$ & 1.0 \\
Not exposed to SHS & $(0.4)$ & 1.0 & $1.0(0.8-1.2)$ \\
Heart disease & 1773 & & 1.0 \\
Exposed to SHS & $(2.4)$ & $0.6(0.5-0.7)$ & 1.0 \\
$\quad$ Not exposed to SHS & $(4.1)$ & 1.0 & 1.0 \\
Hypertension & 5454 & & \\
Exposed to SHS & $(8.4)$ & $0.7(0.6-0.7)$ & $1.1(1.0-1.3)$ \\
Not exposed to SHS & $(12.2)$ & 1.0 & 1.0 \\
\hline
\end{tabular}

*Numbers represent respondents who reported the specific chronic condition. Percentages represent the per cent of individuals by SHS exposure status who reported the specific chronic conditions; 'Adjusted for sex, age group, province, education level, income source, income adequacy, immigration status and presence of children younger than 12 years of age in household

still have been substantial during those times. The fact that the odds of reporting the selected chronic health conditions are generally consistent between never-smokers and ex-smokers may be a reflection of misclassification. Longitudinal data, including a more objective and comprehensive measure of second-hand smoke exposure, would be required to confirm the associations reported here.

Given that the CCHS Cycle 2.1 did not reliably ascertain personal second-hand smoke exposure in homes, and that selfreporting was not time-limited (Cycle 1.1 limited exposure to 'the past month'), it is not surprising that Pérez (44) found a higher prevalence estimate $(33 \%)$ than that reported in the present study. Our overall prevalence estimate for Canada is similar to or lower than that reported for many European countries (49-50), but higher than that reported for the United States (48-50). Our prevalence estimate is likely lower than the true prevalence of second-hand smoke exposure because survey-based exposure assessments have been reported to significantly underestimate second-hand smoke exposure when compared with more objective measurements $(6,12)$. The difference in assessment of second-hand smoke exposure between the survey cycles makes it difficult to draw conclusions about changes over time.

Like Pérez (44), we found that second-hand smoke exposure risk is increased for men, younger ages and residents of Quebec, but we have identified that indexes of low socioeconomic status, such as low income, low education and social assistance receipt, are also risk factors. Studies outside Canada have made similar observations between some indexes of socioeconomic status and second-hand smoke exposure $(7,46,51-53)$. The fact that the most frequent settings of secondhand smoke exposure were public places and workplaces supports the use of public health legislation to help limit second-hand smoke exposure. At the same time, a significant
TABLE 6

Odds of reporting selected chronic conditions among ex-smokers $(n=48,117)$ by second-hand smoke (SHS) exposure status

\begin{tabular}{|c|c|c|c|}
\hline Chronic condition & n (\%) ${ }^{*}$ & $\begin{array}{l}\text { Unadjusted } \\
\text { OR (95\% Cl) }\end{array}$ & $\begin{array}{c}\text { Adjusted } \\
\mathrm{OR}^{\dagger}(95 \% \mathrm{Cl})\end{array}$ \\
\hline Asthma & 3951 & & \\
\hline Exposed to SHS & $(9.3)$ & $1.2(1.1-1.4)$ & $1.2(1.1-1.3)$ \\
\hline Not exposed to SHS & $(7.7)$ & 1.0 & 1.0 \\
\hline Chronic bronchitis & 1329 & & \\
\hline Exposed to SHS & (3.2) & $1.3(1.1-1.5)$ & $1.5(1.3-1.8)$ \\
\hline Not exposed to SHS & $(2.6)$ & 1.0 & 1.0 \\
\hline Emphysema & 674 & & \\
\hline Exposed to SHS & $(1.2)$ & $0.9(0.7-1.1)$ & $1.3(1.0-1.8)$ \\
\hline Not exposed to SHS & $(1.7)$ & 1.0 & 1.0 \\
\hline Heart disease & 3533 & & \\
\hline Exposed to SHS & $(5.9)$ & $0.7(0.6-0.8)$ & $1.1(1.0-1.4)$ \\
\hline Not exposed to SHS & $(8.0)$ & 1.0 & 1.0 \\
\hline Hypertension & 7929 & & \\
\hline Exposed to SHS & $(14.2)$ & $0.8(0.7-0.8)$ & $1.2(1.1-1.3)$ \\
\hline Not exposed to SHS & $(17.5)$ & 1.0 & 1.0 \\
\hline
\end{tabular}

*Numbers represent respondents who reported the specific chronic condition Percentages represent the per cent of individuals by SHS exposure status who reported the specific chronic conditions; ${ }^{\dagger}$ Adjusted for sex, age group, province, education level, income source, income adequacy, immigration status and presence of children younger than 12 years of age in household

proportion of second-hand smoke exposure continues to occur in settings that fall outside of the realm of conventional public health regulation (eg, homes and personal vehicles).

Although firm conclusions on potential causal associations between second-hand smoke exposure and adult respiratory diseases have not yet been reached by scientific experts (36-42), our results contribute to a growing body of literature indicating that second-hand smoke exposure is associated with adult asthma (1-10) and COPD (1-2,9,11-18). In a sample of 4197 never-smoking Swiss adults, self-reported second-hand smoke exposure was associated with greater odds of chronic bronchitis symptoms $(\mathrm{OR}=1.65)$ and physician-diagnosed asthma $(\mathrm{OR}=1.39)(1)$. A recent cohort study of approximately 3000 never-smoking Italian women found that those exposed to second-hand smoke were 2.3 times more likely to have asthma, chronic bronchitis or emphysema (9). Eisner et al have reported that second-hand smoke exposure is directly related in a dose-dependent fashion to increasing asthma (6) and COPD (12) severity, as indicated by respiratory symptoms, corticosteroid and other medication use, hospital admissions and home oxygen use.

The present study is one of the few studies (24) to have reported positive associations between second-hand smoke exposure and hypertension. The absence of significant positive associations in the present study between second-hand smoke exposure and heart disease adds to the controversy on the topic. A meta-analysis of 18 published studies (28) involving more than 650,000 individuals reported a dose-response relationship with coronary artery disease, with RRs of 1.23 for nonsmokers exposed to one to 19 cigarettes/day and 1.31 for nonsmokers exposed to 20 or more cigarettes/day, compared with nonexposed nonsmokers. However, a more recent meta-analysis (35) concluded that when all relevant studies are included and appropriately combined, the risk of death from coronary artery 
disease in never-smokers exposed to second-hand smoke is roughly $5 \%$ and had previously been overestimated. A cohort study (25) though subsequent to this meta-analysis found an excess risk of cardiovascular mortality of approximately $40 \%$ among exposed never-smokers with no baseline cardiovascular disease. Differences in study population, sample size, measurement of second-hand smoke exposure and health outcome, and the control of potentially confounding variables may contribute to discrepancy in results among studies.

\section{CONCLUSIONS}

Approximately 28\% of Canadian current nonsmokers reported regular, recent second-hand smoke exposure in 2000/2001. Risk factors for second-hand smoke exposure were identified. Exposure to second-hand smoke was associated with chronic respiratory and cardiovascular diseases in a very large sample of never- and ex-smokers using a very strict definition of previous smoking. Although the cross-sectional nature of the present

\section{REFERENCES}

1. Leuenberger P, Schwartz J, Ackermann-Liebrich U, et al. Passive smoking exposure in adults and chronic respiratory symptoms (SAPALDIA Study). Swiss Study on Air Pollution and Lung Diseases in Adults, SAPALDIA Team. Am J Respir Crit Care Med 1994;150:1222-8.

2. Robbins AS, Abbey DE, Lebowitz MD. Passive smoking and chronic respiratory disease symptoms in non-smoking adults. Int J Epidemiol 1993;22:809-17.

3. Greer JR, Abbey DE, Burchette RJ. Asthma related to occupational and ambient air pollutants in nonsmokers. J Occup Med 1993;35:909-15.

4. Sippel JM, Pedula KL, Vollmer WM, Buist AS, Osborne ML. Associations of smoking with hospital-based care and quality of life in patients with obstructive airway disease. Chest 1999;115:691-6.

5. Eisner MD, Yelin EH, Katz PP, Earnest G, Blanc PD. Exposure to indoor combustion and adult asthma outcomes: Environmental tobacco smoke, gas stoves, and woodsmoke. Thorax 2002;57:973-8.

6. Eisner MD, Klein J, Hammond SK, Koren G, Lactao G, Iribarren C. Directly measured second hand smoke exposure and asthma health outcomes. Thorax 2005;60:814-21.

7. Irribarren C, Friedman GD, Klatsky AL, Eisner MD. Exposure to environmental tobacco smoke: Association with personal characteristics and self reported health conditions. J Epidemiol Community Health 2001;55:721-8.

8. Menzies D, Nair A, Williamson PA, et al. Respiratory symptoms, pulmonary function, and markers of inflammation among bar workers before and after a legislative ban on smoking in public places. JAMA 2006;296:1742-8.

9. Simoni M, Baldacci S, Puntoni R, et al. Respiratory symptoms/diseases and environmental tobacco smoke (ETS) in never smoker Italian women. Respir Med 2007;101:531-8.

10. Hastert TA, Babey SH, Brown ER, Meng YY. Pets and smoking in the home associated with asthma symptoms and asthma-like breathing problems. Policy Brief UCLA Cent Health Policy Res 2007;(PB2007-2):1-7.

11. Dayal HH, Khuder S, Sharrar R, Trieff N. Passive smoking in obstructive respiratory disease in an industrialized urban population. Environ Res 1994;65:161-71.

12. Eisner MD, Balmes J, Yelin EH, et al. Directly measured secondhand smoke exposure and COPD health outcomes. BMC Pulm Med 2006;6:12.

13. Eisner MD, Balmes J, Katz PP, Trupin L, Yelin EH, Blanc PD. Lifetime environmental tobacco smoke exposure and the risk of chronic obstructive pulmonary disease. Environ Health 2005;4:7.

14. de Marco R, Accordini S, Cerveri I, et al. An international survey of chronic obstructive pulmonary disease in young adults according to GOLD stages. Thorax 2004;59:120-5.

15. Svanes C, Omenaas E, Jarvis D, Chinn S, Gulsvik A, Burney P. Parental smoking in childhood and adult obstructive lung disease: Results from the European Community Respiratory Health Survey. Thorax 2004;59:295-302. data precludes causal inference, given the high prevalence of second-hand smoke exposure in Canada, the associations identified merit further study to help clarify the role of second-hand smoke exposure in healthy individuals, and in those with already established respiratory and cardiovascular disease. Hundreds of municipalities across Canada have already established regulations that limit smoking in public places and the workplace, although they vary in scope and enforceability (44). The Ontario provincial government recently introduced the SmokeFree Ontario Act, which, as of May 31, 2006, comprehensively banned smoking in all workplaces and public places throughout the province, with heavy financial penalties for offenders (58). Other governments in Canada and around the world may need to follow Ontario's lead, and even expand public health efforts to target presently unregulated exposure sites such as homes and personal vehicles, to help protect the health of their residents if the potential deleterious respiratory and other health effects of second-hand smoke exposure are confirmed.
16. Upton MN, Smith GD, McConnachie A, Hart CL, Watt GC. Maternal and personal cigarette smoking synergize to increase airflow limitation in adults. Am J Respir Crit Care Med 2004;169:479-87.

17. Goodman P, Agnew M, McCaffrey M, Paul G, Clancy L. Effects of the Irish smoking ban on respiratory health of bar workers and air quality in Dublin pubs. Am J Respir Crit Care Med 2007;175:840-5.

18. Yin P, Jiang CQ, Cheng KK, et al. Passive smoking exposure and risk of COPD among adults in China: The Guangzhou Biobank Cohort Study. Lancet 2007;370:751-7.

19. Law MR, Morris JK, Wald NJ. Environmental tobacco smoke exposure and ischaemic heart disease: An evaluation of the evidence. BMJ 1997;315:973-80.

20. He J, Vupputuri S, Allen K, Prerost MR, Hughes J, Whelton PK. Passive smoking and the risk of coronary heart disease - a metaanalysis of epidemiologic studies. N Engl J Med 1999;340:920-6.

21. Whincup PH, Gilg JA, Emberson JR, et al. Passive smoking and risk of coronary heart disease and stroke: Prospective study with cotinine measurement. BMJ 2004;329:200-205.

22. Sargent RP, Shepard RM, Glantz SA. Reduced incidence of admissions for myocardial infarction associated with public smoking ban: Before and after study. BMJ 2004;328:977-80.

23. Rosenlund M, Berglind N, Gustavsson A, et al. Environmental tobacco smoke and myocardial infarction among never-smokers in the Stockholm Heart Epidemiology Program (SHEEP). Epidemiology 2001;12:558-64.

24. Dietrich DF, Schwartz J, Schindler C, et al. Effects of passive smoking on heart rate variability, heart rate and blood pressure: An observational study. Int J Epidemiol 2007;36:834-40.

25. Eisner MD, Wang Y, Haight TJ, Balmes J, Hammond SK, Tager IB. Secondhand smoke exposure, pulmonary function, and cardiovascular mortality. Ann Epidemiol 2007;17:364-73.

26. Kauffmann F, Dockery DW, Speizer FE, Ferris BG Jr. Respiratory symptoms and lung function in relation to passive smoking: A comparative study of American and French women. Int J Epidemiol 1989;18:334-44.

27. Hole DJ, Gillis CR, Chopra C, Hawthorne VM. Passive smoking and cardiorespiratory health in a general population in the west of Scotland. BMJ 1989;299:423-7.

28. Schilling RS, Letai AD, Hui SL, Beck GJ, Schoenberg JB, Bouhuys A. Lung function, respiratory disease, and smoking in families. Am J Epidemiol 1977;106:274-83.

29. Enstrom JE, Kabat GC. Environmental tobacco smoke and tobacco related mortality in a prospective study of Californians, 1960-98. BMJ 2003;326:1057.

30. Kuehn BM. Report reviews secondhand smoke risks: Some scientists question risk level. JAMA 2006;296:922-3.

31. Garland C, Barrett-Connor E, Suarez L, Criqui MH, Wingard DL. Effects of passive smoking on ischemic heart disease mortality of nonsmokers: A prospective study. Am J Epidemiol 1985;121:645-50. 
32. Svendsen KH, Kuller LH, Martin MJ, Ockene JK. Effects of passive smoking in the Multiple Risk Factor Intervention Trial. Am J Epidemiol 1987;126:783-95.

33. La Vecchia C, D’Avanzo B, Franzosi MG, Tognoni G. Passive smoking and the risk of acute myocardial infarction GISSI-EFRIM investigations. Lancet 1993;341:505-6.

34. Stranges S, Bonner MR, Fucci F, et al. Lifetime cumulative exposure to secondhand smoke and risk of myocardial infarction in never smokers: Results from the Western New York health study, 1995-2001. Arch Intern Med 2006;166:1961-7.

35. Enstrom JE, Kabat GC. Environmental tobacco smoke and coronary heart disease mortality in the United States a meta-analysis and critique. Inhal Toxicol 2006;18:199-210.

36. United States Department of Health and Human Services. The Health Consequences of Involuntary Smoking: A Report of the Surgeon General. Washington, DC: United States Government Printing Office, 1986:1-359.

37. International Agency for Research on Cancer. IARC Monographs on the Evaluation of the Carcinogenic Risk of Chemicals to Humans: Tobacco Smoking. Lyon: IARC Monograph, 1986;83.

38. United States Environmental Protection Agency. Respiratory Health Effects of Passive Smoking: Lung Cancer and Other Disorders. Washington, DC: United States Environmental Protection Agency, Office of Research and Development, Office of Health and Environmental Assessment, 1992.

39. California Environmental Protection Agency, Office of Environmental Health Hazard Assessment. Health Effects of Exposure to Environmental Tobacco Smoke, 1997.

<www.oehha.org/air/environmental_tobacco/finalets.html> (Version current at June 13, 2008).

40. Scientific Committee on Tobacco and Health. Report of the Scientific Committee on Tobacco and Health. London, United Kingdom: The Stationery Office, 1998;011322124x.

41. Ontario Tobacco Research Unit, University of Toronto. Protection from Second-hand Tobacco Smoke in Ontario: A Review of the Evidence Regarding Best Practices. Toronto: University of Toronto, 2001.

42. United States Department of Health and Human Services. The Health Consequences of Involuntary Exposure to Tobacco Smoke: A Report of the Surgeon General. Washington, DC: United States Government Printing Office, 2006

43. Davey Smith G. Effect of passive smoking on health. BMJ 2003;326:1048-9.

44. Pérez CE. Second-hand smoke exposure - who's at risk? Health Rep 2004;16:9-17.
45. Curtin F, Morabia A, Bernstein M. Lifetime exposure to environmental tobacco smoke among urban women: differences by socioeconomic class. Am J Epidemiol 1998;148:1040-7.

46. Gillespie J, Milne K, Wilson N. Secondhand smoke in New Zealand homes and cars: Exposure, attitudes, and behaviours in 2004. N Z Med J 2005;118:U1782.

47. Wilson N, Thomson G. Still dying from second-hand smoke at work: A brief review of the evidence for smoke-free workplaces in New Zealand. N Z Med J 2002;115:U240.

48. Mannino DM, Siegel M, Rose D, Nkuchia J, Etzel R. Environmental tobacco smoke exposure in the home and worksite and health effects in adults: Results from the 1991 National Health Interview Survey. Tob Control 1997;6:296-305.

49. Janson C, Chinn S, Jarvis D, Zock JP, Toren L, Burney P. Effect of passive smoking on respiratory symptoms, bronchial responsiveness, lung function, and total serum $\operatorname{IgE}$ in the European Community Respiratory Health Survey: A cross-sectional study. Lancet 2001;358:2103-9. (Erratum in 2002;359:360).

50. Janson C, Künzli N, de Marco R, et al. Changes in active and passive smoking in the European Community Respiratory Health Survey. Eur Respir J 2006;27:517-24.

51. Moussa K, Lindström M, Ostergren PO. Socioeconomic and demographic differences in exposure to environmental tobacco smoke at work: The Scania Public Health Survey 2000. Scand J Public Health 2004;32:194-202.

52. Scarinci IC, Watson JM, Slawson DL, Klesges RC, Murray DM, Eck-Clemens LH. Socioeconomic status, ethnicity, and environmental tobacco exposure among non-smoking females. Nicotine Tob Res 2000;2:355-61.

53. Whitlock G, MacMahon S, Vander Hoorn S, Davis P, Jackson R, Norton R. Association of environmental tobacco smoke exposure with socioeconomic status in a population of 7725 New Zealanders. Tob Control 1998;7:276-80.

54. de Groh M, Morrison HI. Environmental tobacco smoke and deaths from coronary heart disease in Canada. Chronic Dis Can 2002;23:13-6.

55. Statistics Canada. Canadian Community Health Survey (CCHS) Cycle 1.1 (2000-2001), Public Use Microdata File Documentation: User Guide. Ottawa: Statistics Canada, 2002.

56. Béland Y. Canadian community health survey - methodological overview. Health Rep 2002;13:9-14.

57. Statistics Canada. Canadian Community Health Survey (CCHS) Cycle 1.1 (2000-2001), Public Use Microdata File: Data Dictionary. Ottawa: Statistics Canada, 2002.

58. Bill 164, Tobacco Control Statute Law Amendment Act (SmokeFree Ontario Act). Ontario Provincial Government, 2006. 


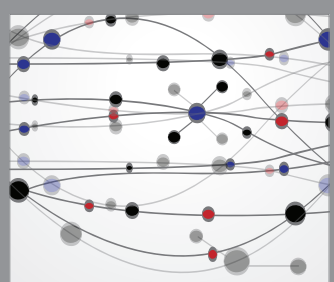

The Scientific World Journal
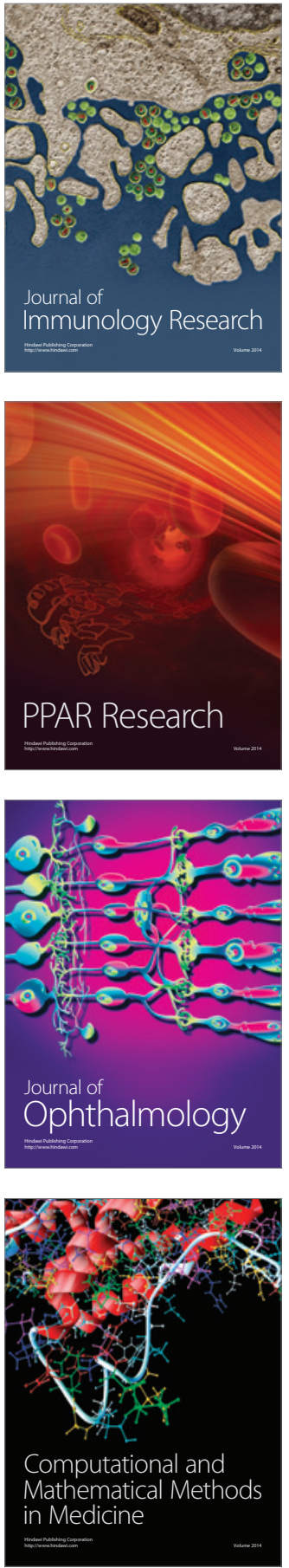

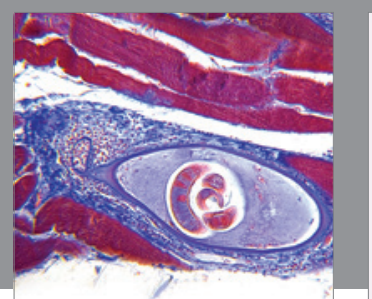

Gastroenterology Research and Practice

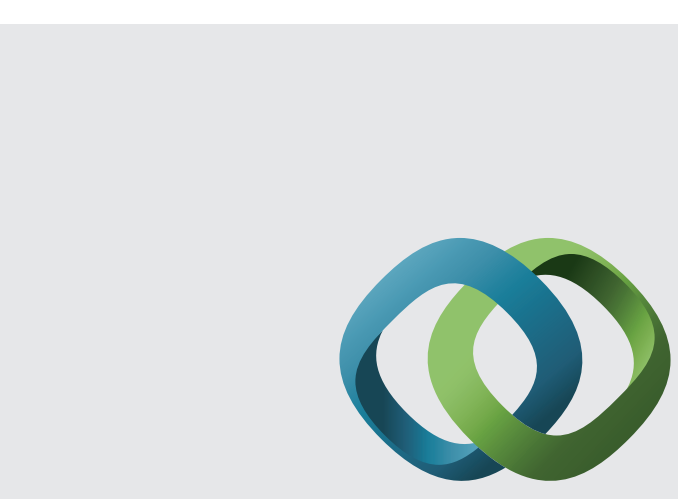

\section{Hindawi}

Submit your manuscripts at

http://www.hindawi.com
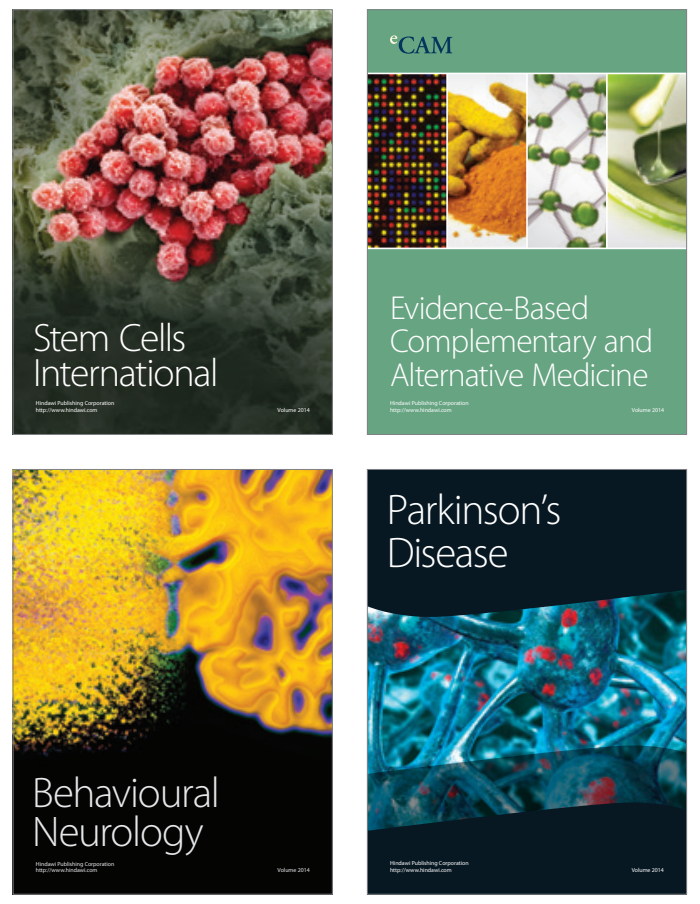
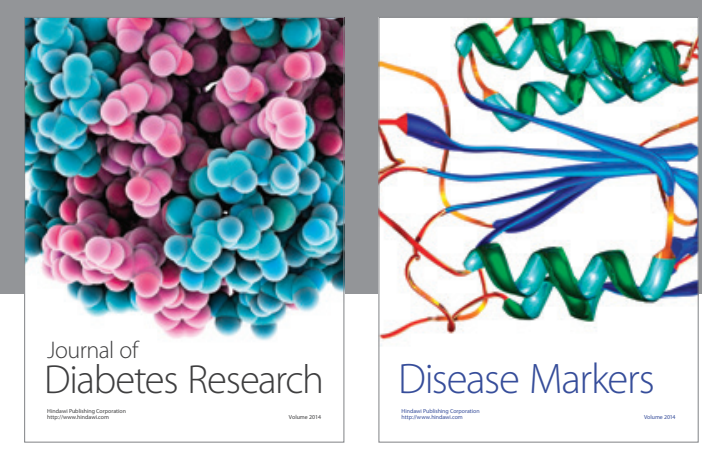

Disease Markers
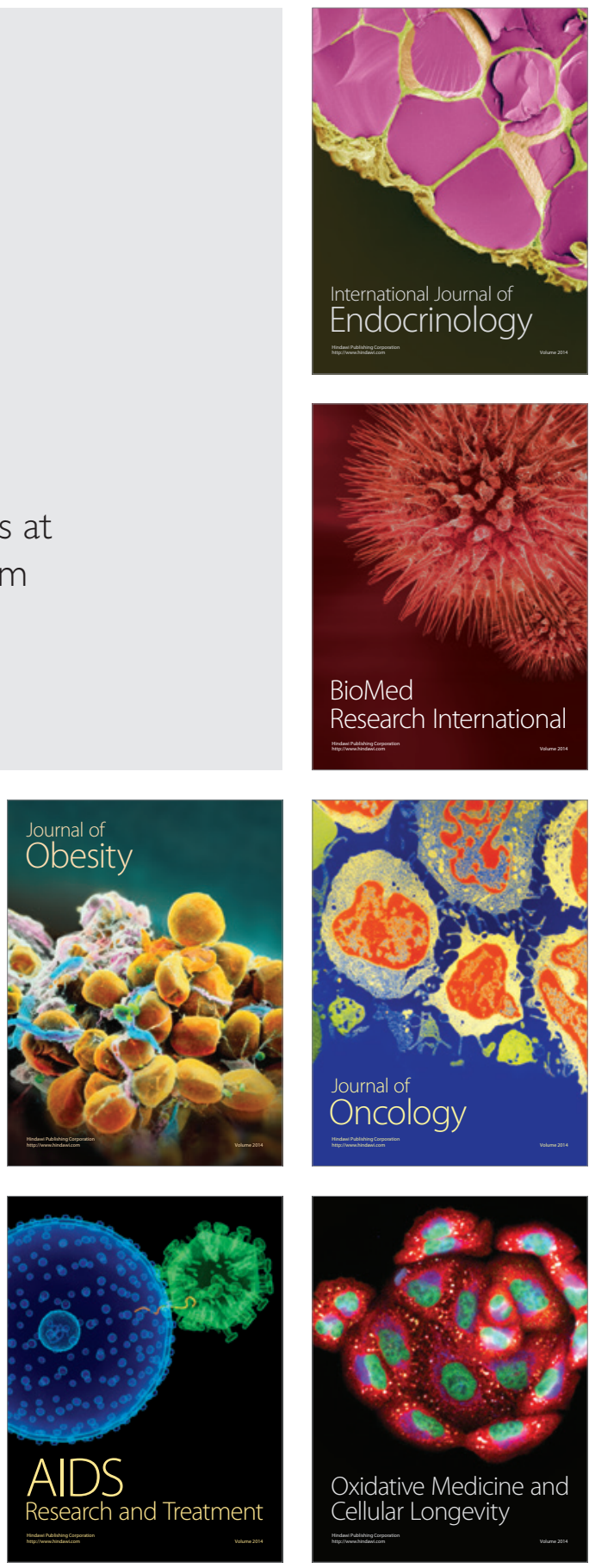